Sains Malaysiana 50(1)(2021): 9-21

http://dx.doi.org/10.17576/jsm-2021-5001-02

\title{
Petrology and Geochemical Features of Semporna Volcanic Rocks, South-east Sabah, Malaysia
}

(Ciri Petrologi dan Geokimia Batuan Volkano Semporna, Tenggara Sabah, Malaysia)

\author{
Elvaene James*, Azman Abdul Ghani, Oluwatoyin O. Akinola \& JunAidi Asis
}

\begin{abstract}
The volcanic rocks in Semporna Peninsula, Sabah, Malaysia forms parts of the Miocene subjected slab during the Miocene-Pliocene orogeny. This study presents new petrographic and geochemical data of volcanic rocks in Semporna area. The volcanic rocks range in composition from basaltic andesite, andesite, dacite to rhyolite, with most of the volcanic shows calc-alkaline affinity with a minor tholeiitic feature. The trace elements shows enrichment in large-ion lithophile elements (LILE) and light rare earth elements (LREE) suggesting that the volcanic rocks have similar geochemical patterns and might come from similar magma source. The petrochemical data suggests that volcanic rocks of Semporna shows characteristic of subduction zone (negative $\mathrm{Nb}, \mathrm{Ta}$, and Ti). Decreasing magnitude of Europium anomalies from intermediate to acid lavas suggests an important role of plagioclase in the fractional crystallization. Negative Ce anomaly in part of Semporna volcanic rocks suggest that those volcanic rocks may related with emergence of oxygenated deep-sea environment. Tectonic diagrams showed that the Semporna volcanic rocks were formed in an island arc setting.
\end{abstract}

Keywords: Calc-alkaline; island arc; Semporna; subduction; volcanic rocks

\section{ABSTRAK}

Batuan volkano Semporna di Semenanjung Semporna, Sabah, Malaysia dihasilkan oleh sebahagian daripada bidur subduksi Miosen semasa orogeni Miosen-Pliosen. Kajian ini membentangkan penemuan baru mengenai data petrografi dan geokimia batuan volkano Semporna daripada batuan pertengahan hingga asid di Semporna. Batuan volkano terdiri daripada andesit basalt, andesit, dasit dan riolit serta semua batuan menunjukkan dominasi kalkalkali dengan sebahagian kecil menunjukkan ciri tholeitik. Unsur-unsur surih menunjukkan pengayaan Unsur Litofil Ion Besar (LILE) dan Unsur Nadir Bumi Ringan (LREE) mencadangkan batuan volkano Semporna mempunyai corak geokimia yang sama serta kemungkinan datang daripada sumber magma yang serupa. Data petrokimia mencadangkan bahawa batuan volkano Semporna menunjukkan ciri-ciri zon benam (anomali Nb, Ta dan Ti negatif). Penurunan anomali Europium daripada lava pertengahan hingga lava berasid menunjukkan peranan penting plagioklas dalam penghabluran berperingkat magma yang berasal daripada mantel. Penurunan Ce anomali pada sebahagian batuan volkano Semporna mencadangkan batuan tersebut mungkin berkaitan dengan kemunculan persekitaran laut dalam yang beroksigen. Rajah tektonik menunjukkan bahawa batuan volkano Semporna terbentuk dalam sekitaran arka kepulauan.

Kata kunci: Arka kepulauan; batuan volkano; benam; kalkalkali; Semporna

\section{INTRODUCTION}

Sabah is located on the northern part of Borneo and surrounded by the South China Sea to the west, the Sulu Sea to the north-east and the Celebes Sea to the southeast (Figure 1). It is surrounded by the Eurasian plate, Indian-Australian plate, Pacific plate, and the Philippines plates (Balaguru \& Hall 2009; Hall 2012; Tongkul 1999). In northern Borneo, the oldest rocks dated back to the Mesozoic is located in the eastern part of Sabah (Semporna and Dent Peninsula), and is part of a basement complex that comprised of various types of igneous and metamorphic rocks (Dhonau \& Hutchison 1966; Kirk 1968; Reinhard \& Wenk 1951). Extension related to slab roll back during subduction of the Sulu Arc had generated granite magmatism which is emplaced as Kinabalu granite during Miocene by break-off of a subjected slab beneath 
Sabah or the possibility of delamination of lithospheric root underneath the Crocker Range (Hall 2013; Rangin et al. 1990). Volcanic activity eastern part of Sabah began in the Early Miocene to Pleistocene in Semporna and Dent Peninsula (Bellon \& Rangin 1991; Bergman et al. 2000; Haile et al. 1965; Kirk 1962, 1968; Rangin et al. 1990; Swauger et al. 1995; Takashima et al. 2005). The Semporna Peninsula consists of areas that includes Semporna, Tawau, and Kunak. The occurrences of volcanic rocks in Semporna area are believed to be south-west onshore continuation of the Sulu Arc from Zamboanga which formed by the subduction of the Celebes Sea (Hall 2013; Rangin \& Silver 1991). The Sulu Arc volcanism in eastern part of Sabah, which are Semporna and Dent Peninsula commenced from Early-Late Miocene (Bellon \& Rangin 1991; Haile et al. 1965; Kirk 1962, 1968; Rangin \& Silver 1991; Swauger et al. 1995) based on evidence of closely association with Kalumpang Formation in Semporna Peninsula (Kirk 1968; Tjia et al. 1992).

Previous petrological and geochemical studies of the volcanic rocks were focused only in Tawau and Kunak area with less study in Semporna vicinity (Bellon \& Rangin 1991; Bergman et al. 2000; Macpherson et al. 2010; Sanudin et al. 2010). This paper presents new petrographic and geochemical data for the Semporna volcanic rocks, using the major and trace elements analysis to investigate the magmatic processes and tectonic environments of the study area.

\section{GEOLOGICAL SETTING}

Northern Borneo lies at a critical junction between the north-west Borneo Trough offshore north-west Sabah along the former Palawan mountains and Proto-Sulu Arc towards offshore of north-east Sabah. The north-west
Borneo trough is situated in southern part of the South China Sea and extends into southern continental margin of the Dangerous Ground and Reed Bank (Hall 2013). Semporna Peninsula categorizes into three morphotectonic units; the Mesozoic oceanic crust, the Middle Miocene volcanic arc, and the Plio-Pleistocene volcanic arc (Sanudin et al. 1995). Semporna is in eastern part of the Semporna Peninsula and extends offshore into Pulau Gaya (Hutchison 2007; Lee 1988). The highest elevation in this area is Mount Conner situated at about $96 \mathrm{~km}$ south of Semporna (Figure 1) which composed of dacitic and rhyolitic rocks. Recent isotopic and geochemical studies suggest that volcanic rocks on the Semporna Peninsula shows an ocean-island basalt (OIB) signature as a result of the Miocene subduction which produced an upwelling of OIB-like magma in the upper mantle into a lithospheric thin spot (Lee 1988).

Between Eocene to Early Miocene, the ProtoSouth China Sea has subducted southwards beneath the northern Borneo (Hall 2012) and caused a collision during the Early Miocene between north Borneo and the continental margin of south China (Hall \& Wilson 2000; Hutchison et al. 2000). Northern Borneo began to emerge by the end of the Early Miocene, while most of the west and eastern parts were still subside below sea level (Balaguru et al. 2003). The volcanic arc in south Sabah formed after the northward subduction of the Celebes Sea. The subduction has initiated on the opening of the Sulu Sea back arc basin followed by slab roll back towards southeast (Hall 2013). However, the arc activity terminated during the late Pliocene (Garwin et al. 2005). Recent study shows the Semporna Peninsula volcanic rocks exhibit the characteristic of subduction-related, OIB-like and MORB (James et al. 2019).

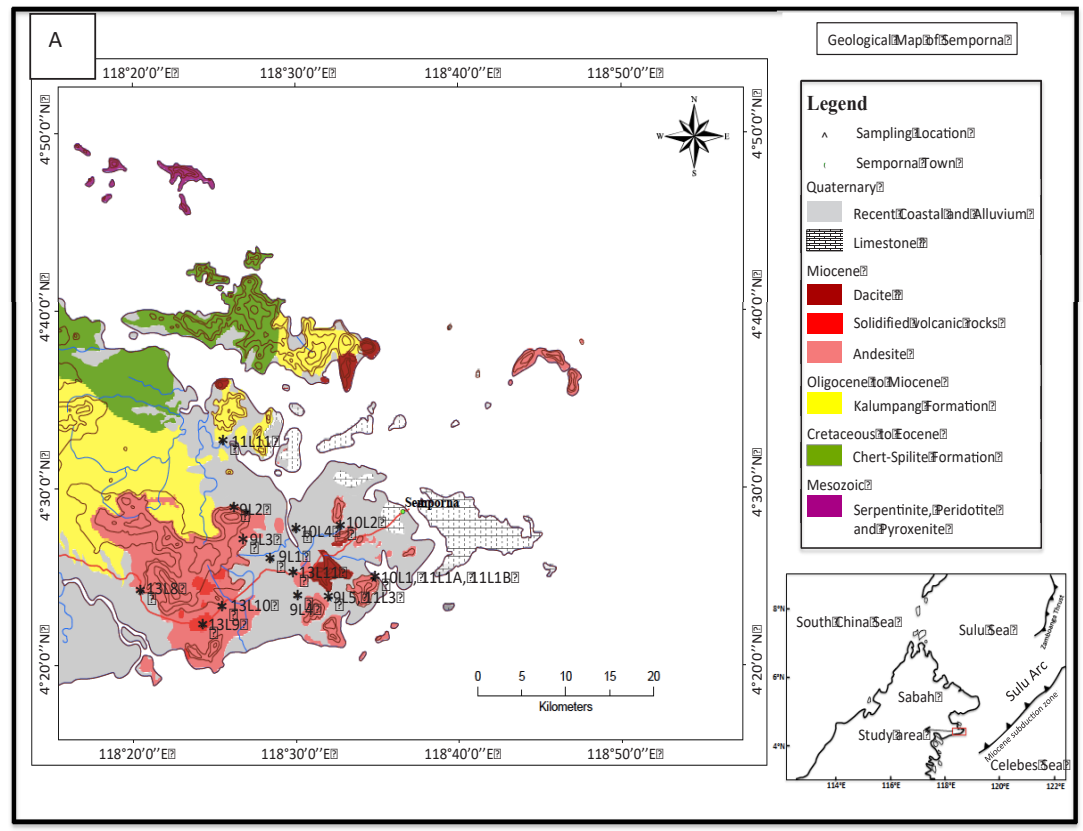




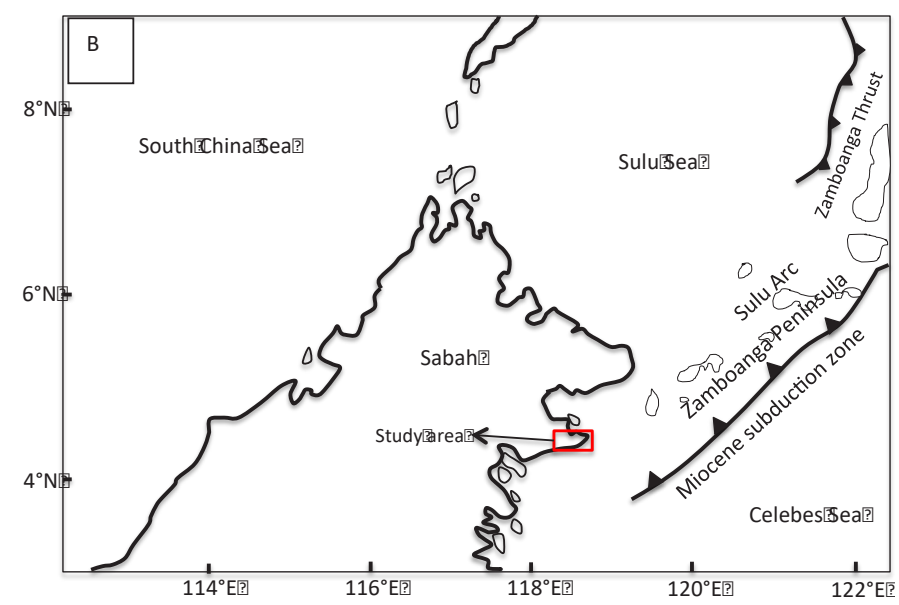

FIGURE 1. (a) Simplified geological map of Semporna located in Sabah and sampling locations in this study. Modified from Kirk (1968), (b) Extention of Zamboanga Peninsula toward Semporna

\section{MATERIALS AND Methods}

Among all the collected samples from Semporna, a total of 16 fresh volcanic rocks samples were carefully selected for petrographic and geochemical analysis (Figure 1). Petrographic analyses and thin section preparation were conducted at the Department of Geology, Faculty of Science, University of Malaya. Geochemical analysis that include both major and trace elements compositions were analysed at the Bureau Veritas Laboratories, Vancouver, Canada for major and trace elements composition (Table 1). Major elements were determined using the X-ray fluorescence (XRF) method. Rock samples were crushed, and pulverized. Samples were mixed with lithium borate inside a platinum crucible then fused at 1100 to 1200 ${ }^{\circ} \mathrm{C}$. After fusion, samples are transferred into a mould to form beads. The fusion beads were analysed using Philip PW 1404/10 X-ray fluorescence spectrometer. Trace elements and rare earth elements (REE), were measured via inductively coupled plasma mass spectrometry (ICP-MS) (Perkin-Elmer Elan 9000). The loss on ignition (LOI) for each sample were determined by weight difference after ignition at $1000{ }^{\circ} \mathrm{C}$. Analytical error for major and trace elements are less than 3 and $7.5 \%$, respectively.

\section{RESULTS}

\section{CLASSIFICATION AND PETROGRAPHIC DESCRIPTION}

Based on TAS classification after Le Maitre et al. (1989), Semporna volcanic rocks range from basaltic andesite, andesite, dacite, and rhyolite and fall under Subalkaline/ Tholeiitic series (Figure 2(a)). Rocks samples contain higher LOI $(>4 \%)$ and might experience alteration. They are classified under Winchester and Floyd (1977) and range from basaltic andesite, andesite, and dacite (Figure 2(b)). Basaltic andesite contains phenocrysts of plagioclase and clinopyroxene enclosed by fine grained plagioclase, clinopyroxene and minor iron oxide groundmass (Figure 3(a)). Plagioclase phenocrysts $(0.1-0.4 \mathrm{~mm}$ in diameter) are subhedral and make up almost $70 \%$ of the rocks. Majority of the clinopyroxene $(0.1-0.3 \mathrm{~mm})$ were altered to uralite with inclusions of iron oxide in some of the clinopyroxene. The brown cryptocrystalline minerals in the groundmass consists of secondary minerals including chlorite and sericite.

Andesite shows a fine-grained and porphyritic texture with phenocryst assemblages of plagioclase, clinopyroxene, hornblende, and biotite. Plagioclase occur as a major phenocryst phase (0.1-1.6 $\mathrm{mm}$ ) as well as in the groundmass. Plagioclase forms a weak alignment indicate the lava flow (Figure 3(b)). Plagioclase zoning is commonly seen in the andesitic unit. Hornblende phenocrysts (0.1-1.0 $\mathrm{mm}$ ) are subhedral, strongly pleochroic and brown in colour. Minor clinopyroxene (augite) and biotite are also observed in andesite. The occurrence of iron oxide is common in the groundmass and are accompanied by quartz, plagioclase, and pyroxene.

Dacite and rhyolite were found in the same outcrop and shared common textural characteristics in hand specimens (Figure 3). The only difference between them is that rhyolite contains more cavities filled with secondary minerals such as chalcedony $(0.2-2.0 \mathrm{~mm})$ compared with dacite. Amygdale texture is common in rhyolite (Figure $3(d))$ and filled cavities contain mineral of secondary 
origin with a low-temperature alteration. Phenocrysts of plagioclase $(0.4-2.0 \mathrm{~mm})$ are colorless, subhedral to euhedral, and show polysynthetic twinning. Zoning of plagioclase is evident in both dacite and rhyolite (Figure 3). Groundmass texture is mostly glassy associated with minor iron oxide, quartz, plagioclase, and alkali feldspar.

TABLE 1. Major, trace, and rare elements of the Semporna volcanic rocks

\begin{tabular}{|c|c|c|c|c|c|c|c|c|}
\hline \multirow[t]{2}{*}{ Sample } & \multicolumn{3}{|c|}{ Basaltic andesite } & \multicolumn{5}{|c|}{ Andesite } \\
\hline & $10 \mathrm{~L} 2$ & 13 L9 & 13 L11 & 9 L4 & 9 L5 & $10 \mathrm{L1}$ & $10 \mathrm{~L} 4$ & $11 \mathrm{~L} 3$ \\
\hline \multicolumn{9}{|c|}{ Major element } \\
\hline $\mathrm{SiO}_{2}$ (wt. \%) & 52.34 & 57.32 & 53.16 & 59.08 & 57.3 & 60.18 & 61.46 & 62.29 \\
\hline $\mathrm{TiO}_{2}$ & 0.85 & 0.67 & 0.68 & 0.52 & 0.87 & 0.59 & 0.40 & 0.57 \\
\hline $\mathrm{Al}_{2} \mathrm{O}_{3}$ & 21.3 & 17.42 & 18.04 & 16.55 & 17.07 & 16.33 & 14.83 & 14.28 \\
\hline $\mathrm{FeO} *$ & 5.31 & 1.63 & 9.73 & 5.95 & 7.35 & 5.94 & 4.52 & 4.22 \\
\hline $\mathrm{MnO}$ & 0.02 & 0.01 & 0.18 & 0.07 & 0.15 & 0.11 & 0.14 & 0.21 \\
\hline $\mathrm{MgO}$ & 1.44 & 0.06 & 4.04 & 2.60 & 2.48 & 2.57 & 1.01 & 1.33 \\
\hline $\mathrm{CaO}$ & 7.45 & 0.32 & 8.28 & 5.40 & 6.70 & 5.95 & 4.90 & 5.01 \\
\hline $\mathrm{Na}_{2} \mathrm{O}$ & 2.60 & 1.36 & 2.67 & 2.22 & 2.81 & 2.53 & 2.56 & 3.45 \\
\hline $\mathrm{K}_{2} \mathrm{O}$ & 0.18 & 1.89 & 1.30 & 1.03 & 2.04 & 2.36 & 2.65 & 1.66 \\
\hline $\mathrm{P}_{2} \mathrm{O}_{5}$ & 0.25 & 0.26 & 0.19 & 0.13 & 0.30 & 0.17 & 0.14 & 0.13 \\
\hline LOI & 8.10 & 18.80 & 1.50 & 6.30 & 2.80 & 3.10 & 7.30 & 6.70 \\
\hline Total & 99.84 & 99.74 & 99.77 & 99.85 & 99.87 & 99.83 & 99.91 & 99.85 \\
\hline \multicolumn{9}{|l|}{ Trace element } \\
\hline $\mathrm{Ba}(\mathrm{ppm})$ & 87 & 742 & 233 & 415 & 281 & 366 & 458 & 340 \\
\hline $\mathrm{Be}$ & 2 & 0 & 0 & 0 & 1 & 0 & 2 & 1 \\
\hline Co & 11.4 & 0.6 & 23.3 & 15.2 & 12.6 & 12.7 & 10.6 & 5.4 \\
\hline Cs & 0.2 & 0 & 2.7 & 4.8 & 1.7 & 6.1 & 5.8 & 3.1 \\
\hline $\mathrm{Ga}$ & 23.2 & 9.9 & 16.4 & 16.7 & 17.1 & 15.2 & 13.7 & 15.6 \\
\hline Hf & 2 & 2.3 & 1.8 & 3 & 3 & 2.8 & 2.2 & 4.4 \\
\hline $\mathrm{Nb}$ & 1.9 & 2.2 & 1.4 & 3.1 & 3.3 & 2.9 & 1.8 & 5.1 \\
\hline $\mathrm{Rb}$ & 4.1 & 4.3 & 44.7 & 32.1 & 40.4 & 86.1 & 88.6 & 74.8 \\
\hline $\mathrm{Sn}$ & 1 & 4 & 0 & 0 & 0 & 0 & 0 & 1 \\
\hline $\mathrm{Sr}$ & 528 & 440.9 & 35.5 & 292.1 & 340.3 & 296.7 & 219.3 & 213.1 \\
\hline $\mathrm{Ta}$ & 0.1 & 0.2 & 0.1 & 0.3 & 0.1 & 0.2 & 0.2 & 0.3 \\
\hline Th & 2.6 & 8.1 & 4.6 & 8 & 3.5 & 6.7 & 8.7 & 6.3 \\
\hline $\mathrm{U}$ & 0.5 & 1.5 & 1 & 1.2 & 0.9 & 2 & 2.1 & 1.4 \\
\hline $\mathrm{V}$ & 166 & 177 & 184 & 117 & 131 & 121 & 52 & 55 \\
\hline W & 1.1 & 9 & 0 & 0 & 0.5 & 1.2 & 1 & 0.6 \\
\hline $\mathrm{Zr}$ & 72.9 & 81.1 & 63.4 & 106.3 & 102.3 & 99.2 & 77 & 169.9 \\
\hline $\mathrm{Y}$ & 39.7 & 6.4 & 16 & 47.8 & 32.6 & 20.5 & 37.1 & 36.7 \\
\hline $\mathrm{La}$ & 39.9 & 31.2 & 13.5 & 21 & 17.2 & 16.2 & 29.1 & 22.9 \\
\hline $\mathrm{Ce}$ & 22.9 & 59.7 & 28.1 & 32.6 & 36.9 & 31.7 & 42.5 & 41.2 \\
\hline
\end{tabular}




\begin{tabular}{|c|c|c|c|c|c|c|c|c|}
\hline $\operatorname{Pr}$ & 9.85 & 6.62 & 3.59 & 4.32 & 4.7 & 4.05 & 6.22 & 5.04 \\
\hline $\mathrm{Nd}$ & 43.3 & 25.3 & 15.6 & 18.3 & 20 & 16 & 25 & 19.9 \\
\hline $\mathrm{Sm}$ & 9.25 & 4.38 & 3.11 & 3.71 & 4.9 & 3.59 & 6.23 & 4.5 \\
\hline $\mathrm{Eu}$ & 2.88 & 1.25 & 1.04 & 0.99 & 1.5 & 0.87 & 2.23 & 1.13 \\
\hline $\mathrm{Gd}$ & 9.39 & 3.31 & 3.06 & 4.39 & 5.74 & 3.69 & 7.36 & 4.96 \\
\hline $\mathrm{Tb}$ & 1.28 & 0.37 & 0.48 & 0.65 & 0.93 & 0.56 & 1.14 & 0.84 \\
\hline Dy & 7.54 & 1.65 & 2.91 & 4.41 & 5.72 & 3.52 & 6.92 & 5.5 \\
\hline Ho & 1.39 & 0.25 & 0.64 & 1.05 & 1.18 & 0.73 & 1.51 & 1.2 \\
\hline $\mathrm{Er}$ & 3.77 & 0.69 & 1.89 & 3.36 & 3.6 & 2.15 & 4.25 & 3.84 \\
\hline $\mathrm{Tm}$ & 0.43 & 0.11 & 0.25 & 0.42 & 0.5 & 0.33 & 0.55 & 0.55 \\
\hline $\mathrm{Yb}$ & 2.64 & 0.74 & 1.68 & 2.74 & 3.4 & 2.34 & 3.73 & 3.54 \\
\hline $\mathrm{Lu}$ & 0.38 & 0.11 & 0.26 & 0.45 & 0.51 & 0.34 & 0.6 & 0.6 \\
\hline $\mathrm{La}_{\mathrm{N}} / \mathrm{Sm}_{\mathrm{N}}$ & 2.71 & 4.48 & 2.73 & 3.56 & 2.21 & 2.84 & 2.94 & 3.20 \\
\hline $\mathrm{Gd}_{\mathrm{N}} / \mathrm{Lu}_{\mathrm{N}}$ & 3.07 & 3.73 & 1.46 & 1.21 & 1.40 & 1.35 & 1.53 & 1.03 \\
\hline $\mathrm{Eu} / \mathrm{Eu}^{*}$ & 0.94 & 1.00 & 1.03 & 0.75 & 0.86 & 0.73 & 1.01 & 0.73 \\
\hline \multicolumn{9}{|c|}{ Table 1 continued } \\
\hline \multirow[t]{2}{*}{ Sample } & \multicolumn{2}{|c|}{ Andesite } & \multicolumn{4}{|c|}{ Dacite } & \multicolumn{2}{|c|}{ Rhyolite } \\
\hline & 11 L11 & $13 \mathrm{~L} 10$ & $9 \mathrm{~L} 1$ & $9 \mathrm{~L} 3$ & $11 \mathrm{~L} 1 \mathrm{~A}$ & $13 \mathrm{~L} 8$ & $9 \mathrm{~L} 2$ & $11 \mathrm{~L} 1 \mathrm{~B}$ \\
\hline \multicolumn{9}{|l|}{ Major element } \\
\hline $\mathrm{SiO}_{2}$ (wt. \%) & 56.95 & 61.32 & 69.22 & 64.66 & 66.63 & 64.53 & 74.8 & 70.97 \\
\hline $\mathrm{TiO}_{2}$ & 0.67 & 0.54 & 0.38 & 0.37 & 0.42 & 0.50 & 0.44 & 0.43 \\
\hline $\mathrm{Al}_{2} \mathrm{O}_{3}$ & 15.61 & 16.65 & 13.06 & 15.81 & 14.08 & 14.28 & 13.29 & 13.87 \\
\hline $\mathrm{FeO} *$ & 5.38 & 5.65 & 3.54 & 4.61 & 3.24 & 3.83 & 3.01 & 3.39 \\
\hline $\mathrm{MnO}$ & 0.15 & 0.11 & 0.07 & 0.10 & 0.03 & 0.09 & 0.04 & 0.04 \\
\hline $\mathrm{MgO}$ & 1.72 & 2.64 & 0.77 & 1.48 & 0.47 & 1.02 & 0.20 & 0.57 \\
\hline $\mathrm{CaO}$ & 7.29 & 5.28 & 3.64 & 3.78 & 2.82 & 4.35 & 0.24 & 1.67 \\
\hline $\mathrm{Na}_{2} \mathrm{O}$ & 3.93 & 2.92 & 2.47 & 3.70 & 2.86 & 3.09 & 3.02 & 3.34 \\
\hline $\mathrm{K}_{2} \mathrm{O}$ & 0.83 & 2.16 & 2.15 & 2.52 & 2.64 & 1.14 & 2.83 & 3.98 \\
\hline $\mathrm{P}_{2} \mathrm{O}_{5}$ & 0.13 & 0.17 & 0.13 & 0.13 & 0 & 0.09 & 0.05 & 0.01 \\
\hline LOI & 7.20 & 2.40 & 4.50 & 2.70 & 6.60 & 6.90 & 1.90 & 1.60 \\
\hline Total & 99.86 & 99.84 & 99.93 & 99.86 & 99.79 & 99.82 & 99.82 & 99.87 \\
\hline \multicolumn{9}{|l|}{ Trace element } \\
\hline $\mathrm{Ba}(\mathrm{ppm})$ & 138 & 341 & 341 & 399 & 801 & 422 & 947 & 436 \\
\hline $\mathrm{Be}$ & 0 & 2 & 0 & 2 & 3 & 0 & 4 & 0 \\
\hline Co & 12.3 & 16.4 & 4.3 & 8 & 3.1 & 5.3 & 2.4 & 4 \\
\hline Cs & 5.9 & 2.4 & 12.9 & 6.5 & 23.7 & 4.7 & 18.9 & 1.6 \\
\hline $\mathrm{Ga}$ & 16.9 & 15.9 & 12.2 & 16 & 16.6 & 13.5 & 12.9 & 17.2 \\
\hline $\mathrm{Hf}$ & 3.1 & 2.4 & 2 & 2.7 & 6.1 & 5.6 & 4.7 & 5.5 \\
\hline $\mathrm{Nb}$ & 1.5 & 3.2 & 1.9 & 2.1 & 6.6 & 5.7 & 5.4 & 6.2 \\
\hline $\mathrm{Rb}$ & 17.1 & 63.8 & 86.1 & 97.7 & 279.1 & 37.3 & 57.7 & 99.3 \\
\hline Sn & 0 & 0 & 0 & 0 & 2 & 2 & 2 & 2 \\
\hline $\mathrm{Sr}$ & 715.9 & 377.4 & 176.1 & 319.2 & 324.8 & 253.1 & 163.1 & 111.9 \\
\hline
\end{tabular}




\begin{tabular}{|c|c|c|c|c|c|c|c|c|}
\hline $\mathrm{Ta}$ & 0.1 & 0.2 & 0 & 0.2 & 0.3 & 0.3 & 0.4 & 0.4 \\
\hline Th & 2.5 & 8.6 & 7.9 & 9.1 & 9.4 & 7.8 & 7.7 & 9.4 \\
\hline $\mathrm{U}$ & 0.8 & 2.1 & 1.7 & 2.1 & 2.1 & 2.3 & 1.9 & 2.9 \\
\hline V & 118 & 111 & 51 & 63 & 32 & 34 & 19 & 36 \\
\hline $\mathrm{W}$ & 0 & 0.9 & 0.8 & 1 & 0 & 0.6 & 0.8 & 0.7 \\
\hline $\mathrm{Zr}$ & 104.5 & 93.5 & 69.4 & 90.3 & 220.4 & 202.9 & 195.5 & 217.6 \\
\hline Y & 32.2 & 28.7 & 12.8 & 10.8 & 43.5 & 39.6 & 51.2 & 63 \\
\hline $\mathrm{La}$ & 10 & 28.7 & 14.1 & 17.1 & 32.3 & 22.7 & 64.6 & 40.2 \\
\hline $\mathrm{Ce}$ & 21.4 & 45.8 & 25.4 & 32.2 & 35.3 & 45.4 & 133.9 & 42.3 \\
\hline $\operatorname{Pr}$ & 3.21 & 6.78 & 2.94 & 3.52 & 8.87 & 5.78 & 16.66 & 11.73 \\
\hline $\mathrm{Nd}$ & 14.7 & 26.9 & 11.1 & 12.9 & 36.4 & 23.8 & 59.1 & 49.4 \\
\hline $\mathrm{Sm}$ & 3.81 & 6.19 & 2.35 & 2.35 & 8.33 & 5.74 & 12.19 & 12.06 \\
\hline $\mathrm{Eu}$ & 1.13 & 2.24 & 0.67 & 0.7 & 1.85 & 1.29 & 2.28 & 2.07 \\
\hline $\mathrm{Gd}$ & 4.75 & 6.49 & 2.37 & 2.11 & 7.58 & 6.28 & 9.62 & 11.87 \\
\hline $\mathrm{Tb}$ & 0.79 & 1.05 & 0.35 & 0.29 & 1.25 & 1.06 & 1.54 & 1.93 \\
\hline Dy & 5.12 & 5.87 & 2.27 & 1.81 & 7.66 & 6.55 & 9.32 & 11.65 \\
\hline Но & 1.14 & 1.17 & 0.45 & 0.36 & 1.69 & 1.42 & 1.89 & 2.45 \\
\hline $\mathrm{Er}$ & 3.3 & 3.31 & 1.31 & 1.14 & 5.06 & 4.62 & 5.97 & 7.4 \\
\hline $\mathrm{Tm}$ & 0.47 & 0.45 & 0.18 & 0.15 & 0.72 & 0.63 & 0.9 & 1.09 \\
\hline $\mathrm{Yb}$ & 3.21 & 2.99 & 1.34 & 1.18 & 4.95 & 4.36 & 6.05 & 7.19 \\
\hline $\mathrm{Lu}$ & 0.46 & 0.39 & 0.2 & 0.17 & 0.76 & 0.69 & 0.96 & 1.08 \\
\hline $\mathrm{La}_{\mathrm{N}} / \mathrm{Sm}_{\mathrm{N}}$ & 1.65 & 2.92 & 3.77 & 4.58 & 2.44 & 2.49 & 3.33 & 2.10 \\
\hline $\mathrm{Gd}_{\mathrm{N}} / \mathrm{Lu}_{\mathrm{N}}$ & 1.28 & 2.07 & 1.47 & 1.54 & 1.24 & 1.13 & 1.25 & 1.37 \\
\hline $\mathrm{Eu} / \mathrm{Eu}^{*}$ & 0.81 & 1.08 & 0.87 & 0.94 & 0.71 & 0.66 & 0.64 & 0.53 \\
\hline
\end{tabular}
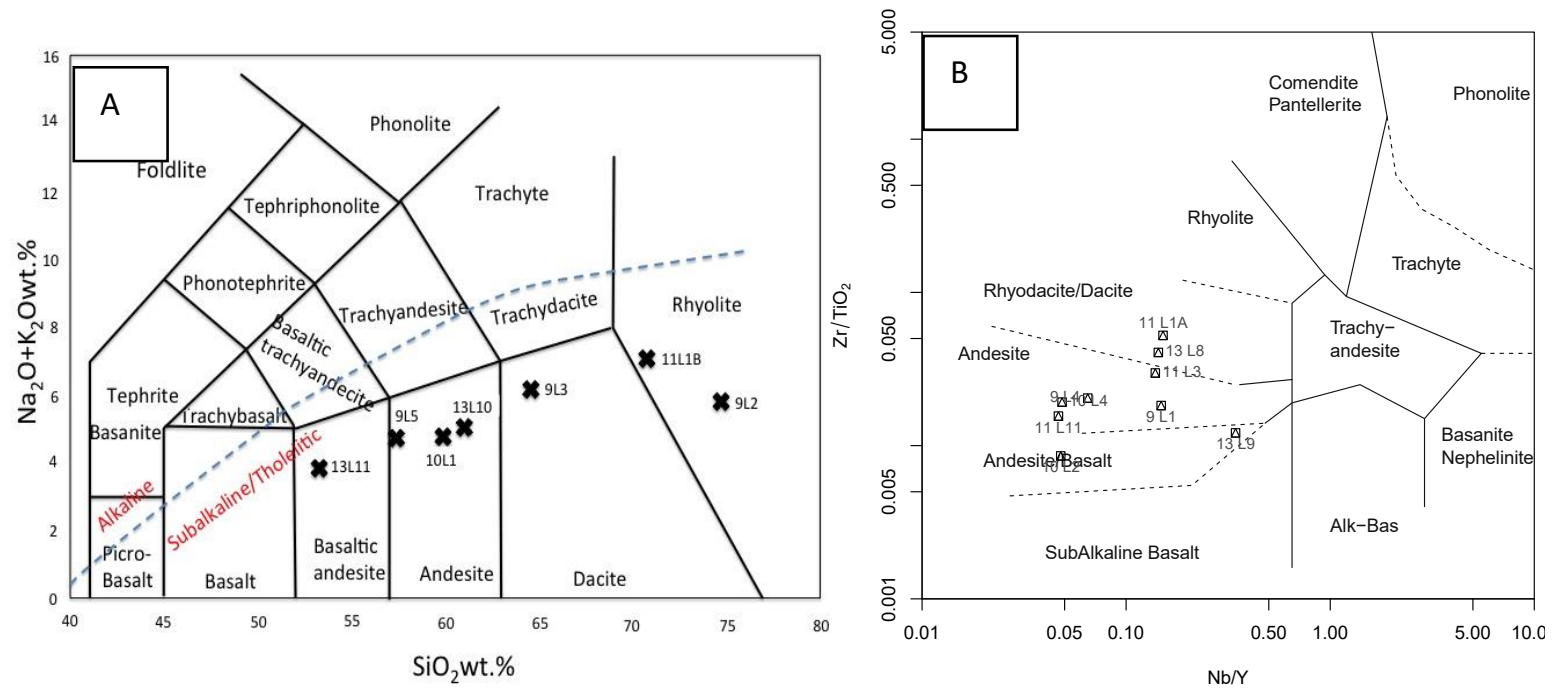

FIGURE 2. (a) $\mathrm{Na}_{2} \mathrm{O}$ wt. $\%+\mathrm{K}_{2} \mathrm{O}$ wt. $\%$ vs. $\mathrm{SiO}_{2}$ wt. $\%$ diagram for the Semporna volcanic samples (after Le Maitre et al. (1989)). (b) $\mathrm{Zr} / \mathrm{TiO} 2 \mathrm{vs} \mathrm{Nb/Y} \mathrm{diagram} \mathrm{(after} \mathrm{Winchester} \mathrm{and} \mathrm{Floyd} \mathrm{(1977))}$ 

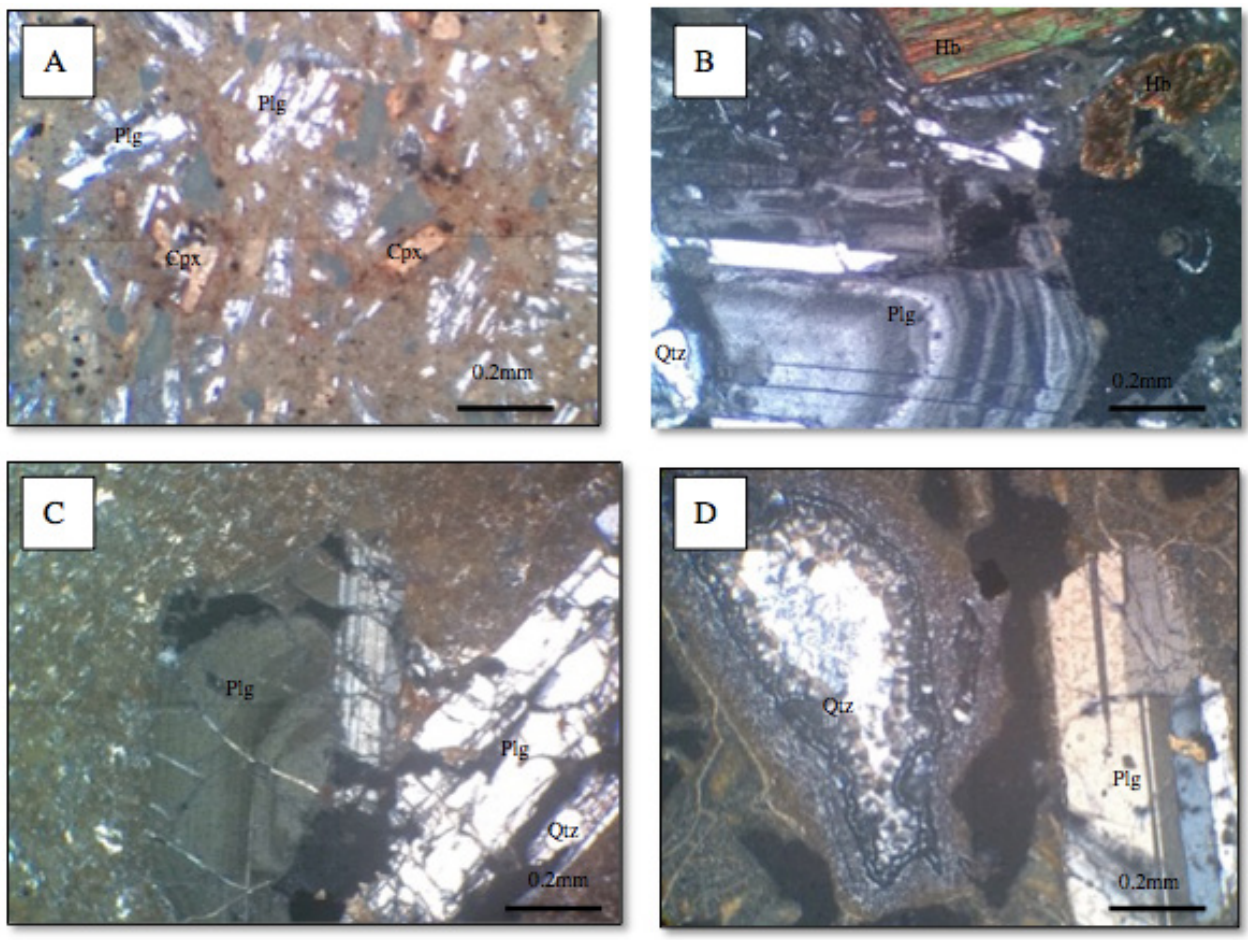

FIGURE 3. Photomicrograph of Semporna volcanic rocks, (a) Subhedral plagioclase and altered clinopyroxene with cryptocrystalline groundmass in basaltic andesite, (b) Zoned plagioclase and subhedral hornblende in andesite and weak alignment shows by smaller size plagioclase, (c) Zoned and polysynthetic twinning plagioclase as phenocryst in dacite, (d) Amygdoloidal texture composed of quartz chalcedony and plagioclase phenocryst enclosed by glass groundmass in rhyolite

MAJOR ELEMENTS AND TRACE ELEMENTS

$\mathrm{SiO}_{2}$ contents for basaltic andesite range from 52.34 - 57.32 wt. $\%$ and total alkali from 2.78 - 3.97 wt. \%. Andesite have range of $\mathrm{SiO}_{2}$ contents from $56.95-62.29$ wt. \%, with total alkali from $3.25-5.21$ wt. \%. The $\mathrm{SiO}_{2}$ content for dacite range from 64.53 - 69.22-wt. \%, with total alkali from 4.23 - $6.22 \mathrm{wt}$ \% (Table 1). Rhyolite yield relatively high $\mathrm{SiO}_{2}$ and total alkali compared to basaltic andesite, andesite and dacite which ranges from 70.97 74.80 wt. $\%$ and $5.85-7.32$ wt. \%, respectively (Table 1). There is a positive correlation between $\mathrm{K}_{2} \mathrm{O}$ and $\mathrm{SiO}_{2}$, and the volcanic rocks range from tholeiite series to high-K calc-alkaline series. Most of the units are plotted within the calc-alkaline series, except for some andesite and rhyolite, which fall under the high-K calc-alkaline series and one basaltic andesite (10L2) in the tholeiite series (figure not shown). All the Semporna volcanic rocks show both increasing and decreasing trends from basaltic andesite to rhyolite on Harker diagrams (Figure 4). Major elements such as $\mathrm{TiO}_{2}, \mathrm{Al}_{2} \mathrm{O}_{3}, \mathrm{FeO}(\mathrm{t}), \mathrm{MgO}, \mathrm{CaO}$, and $\mathrm{P}_{2} \mathrm{O}_{5}$ shows negative correlation, while $\mathrm{K}_{2} \mathrm{O}$ show a positive correlation with $\mathrm{SiO}_{2}$. Decreasing trends shown by $\mathrm{Al}_{2} \mathrm{O}_{3}$ and $\mathrm{CaO}$ with increasing $\mathrm{SiO}_{2}$ indicating the fractionation of plagioclase and hornblende (Liu 2005), while $\mathrm{TiO}_{2}$ and $\mathrm{P}_{2} \mathrm{O}_{5}$ also portray a decreasing trend with increasing $\mathrm{SiO}_{2}$, which might be related to the fractional crystallization of apatite, rutile, and ilmenite during magma evolution (Liu 2005). Scattered pattern shown in plot of $\mathrm{Na}_{2} \mathrm{O}$ vs $\mathrm{SiO}_{2}$ suggest post magmatic alteration (Liu 2005) which supported by presence of alteration minerals observed in thin section. Continuous pattern shown that Semporna volcanic rocks are formed from a co-magmatic series.

The Semporna volcanic rocks ranging from basaltic andesite to rhyolite display a significant variation of LILE (Large-Ion Lithophile Elements). Ba and $\mathrm{Rb}$ show positive correlation with increasing $\mathrm{SiO}_{2}$ which clearly indicate enrichment of alkali feldspar and biotite (Di Vincenzo et al. 1996; Imeokparia 1981). In contrast, $\mathrm{Sr}$ shows negative correlation with increasing $\mathrm{SiO}_{2}$. Multielements spider-plot (Figure 5(a)) shows that most of the volcanic rocks in the study area are characterized by: negative $\mathrm{Nb}$, Ta, Ti anomalies, enrichment of LILE (Ba, Sr, and $\mathrm{Rb}$ ), and slightly positive to negative $\mathrm{Zr}$ anomalies. Volcanic rocks that occur in subduction-related domains 
are usually depleted in HFSE ( $\mathrm{Nb}, \mathrm{Ta}$, and Ti) and enrichment in LILE (Stolz et al. 1996; Xia \& Li 2019). Observation in primitive mantle normalised Semporna volcanic rocks show signatures that are similar pattern to typical subduction zones (e.g. enrichment of LILE and a depleted $\mathrm{Nb}$, Ta, and $\mathrm{Ti}$ ) and are comparable to the Mariana Arc (Sarbas 2008) which exhibits subductionrelated features. Enrichments of LILE (e.g. Ba, Sr, and $\mathrm{Rb}$ ) and depletion of $\mathrm{Nb}, \mathrm{Ta}, \mathrm{Z}$, and $\mathrm{Ti}$ in primitive mantle normalised Semporna volcanic rocks are consistent with transportation of fluid-soluble elements into the mantle wedge source region in subduction zone magmas (Stern 2002; Tastumi \& Eggins 1995). Th and Be are relatively low in Semporna volcanic rocks. This suggest less sediment involvement in the subduction processes (Stern 2002) since $\mathrm{Th}$ and Be are highly soluble in hydrous silicate melt (Zheng 2019).

Chondrite-normalized REE plot (Figure 5(b)) shows Semporna volcanic rocks display slight enrichment of light rare earth element (LREE) $(\mathrm{La} / \mathrm{SmN}=1.65$ - 4.58) compared to heavy rare earth elements (HREE) $(\mathrm{Gd} / \mathrm{LuN}$
$=1.65-3.73)$. Most Semporna volcanic rocks exhibits weak negative Eu anomalies $\left(\mathrm{Eu} / \mathrm{Eu}^{*}=0.53\right.$ - 0.93), except four samples (10L4, 13L9, 13L10, and 13L11) which show absent or small positive Eu anomalies (Eu/ $\mathrm{Eu}^{*}=1.00$ - 1.08) (Figure 5(b); Table 1). Slightly positive $\mathrm{Eu}$ anomalies may suggest accumulation of plagioclase and negative $\mathrm{Eu}$ anomalies indicating that plagioclase fractionation played a significant role during evolution of these magmas (Zhou \& Mukasa 1997). In REE patterns, noticeable negative Ce anomaly present slightly in andesite (9L4, 10L4, 11L1A, and 11L11), dacite (11L1A) and rhyolite (11L1B), while strong negative Ce anomaly observed in basaltic andesite (10L2) (Figure 5(a)), showing that those volcanic rocks may related with emergence of oxygenated deep-sea environment (Kato et al. 2002). The weak $\mathrm{Ce}$ anomaly in andesite, dacite and rhyolite in Semporna may indicate near-shore and ocean margin seawater settings (Johannesson et al. 2006) while basaltic andesite occurs in the modern open ocean setting (Tostevin et al. 2016). Semporna volcanic rock REE patterns suggest the rocks are co-magmatic.
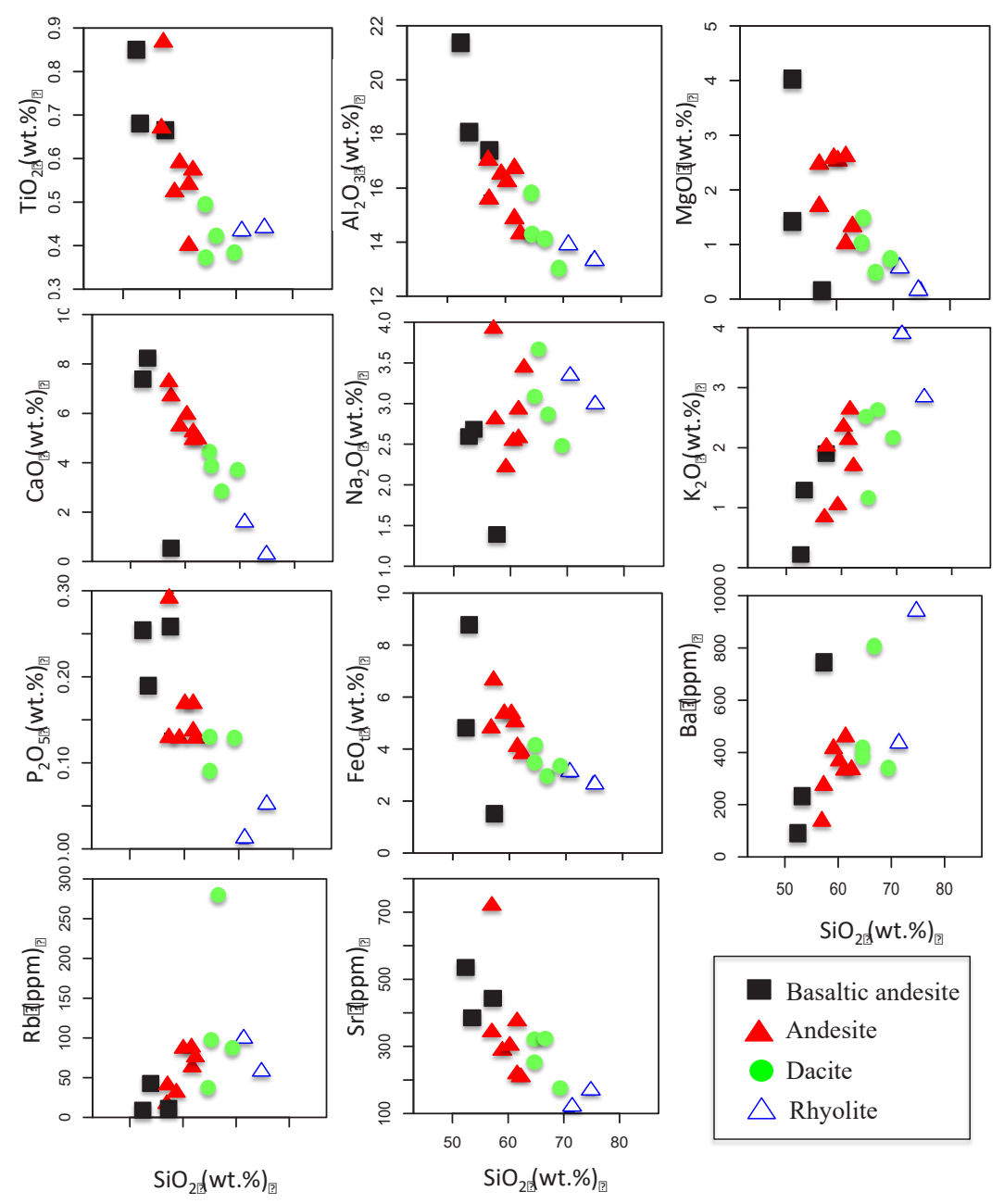

FIGURE 4. Harker diagrams of major elements and selected trace elements of Semporna volcanic rocks 

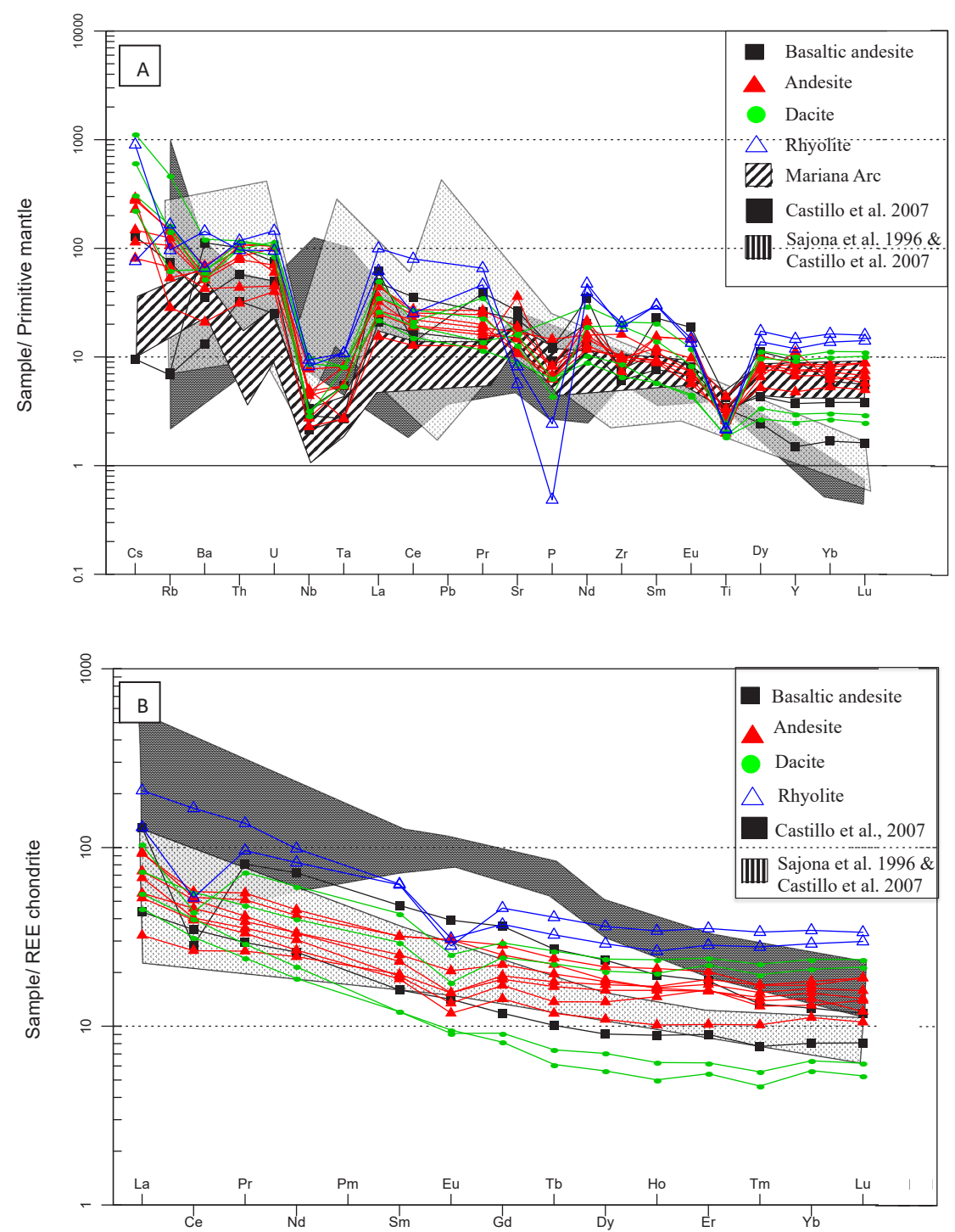

FIGURE 5. (a) Primitive mantle-normalized patterns for the Semporna volcanic rocks, (b) Chondrite-normalized patterns for the Semporna volcanic rocks

\section{DISCUSSION}

\section{MAGMA DIFFERENTIATION AND TECTONIC SETTING}

Major and trace elements signatures for Semporna volcanic rocks show: Variation in trends of major elements against $\mathrm{SiO}_{2}$ indicating magma differentiation $\left(\mathrm{SiO}_{2}\right.$ vs. $\mathrm{TiO}_{2}, \mathrm{Al}_{2} \mathrm{O}_{3}, \mathrm{FeO}(\mathrm{t}), \mathrm{MgO}, \mathrm{CaO}, \mathrm{K}_{2} \mathrm{O}$, and $\mathrm{P}_{2} \mathrm{O}_{5}$ ) and dominance of plagioclase fractionation $\left(\mathrm{SiO}_{2} \mathrm{vs} . \mathrm{Al}_{2} \mathrm{O}_{3}\right.$ and $\mathrm{CaO}$; negative Eu anomalies); the increasing fractionated REE patterns (Figure 5(b)) $\left(\left(\mathrm{La}_{\mathrm{N}} / \mathrm{Yb}_{\mathrm{N}}\right)=2.10-28.48\right)$ and negative $\mathrm{Eu}$ anomalies in Semporna lavas indicate that the magma has experienced magma differentiation and fractional crystallization from basaltic andesite to andesite and later to more evolved dacite and rhyolite; and all the rock exhibit typical subduction-related characteristics evidenced by enrichment of LILE and depletion of $\mathrm{Nb}$, $\mathrm{Ta}$, and Ti.

Even though Semporna volcanic rocks show some attributes of subalkaline/tholeiitic series, however, most of the rocks plotted in the calc-alkaline series (figure not shown here). In the surrounding regions, Semporna volcanic rocks shared a similar calc-alkaline and tholeiitic distribution with magma suites from Dent Peninsula (Bergman et al. 2000), north-eastern Sulu Arc (Castillo et al. 2007; Sajona et al. 1996), central Sulu basaltic andesite (Castillo et al. 2007) and eastern Mindanao (Sonntag et al. 2011), where all rocks had formed at convergent margin in the Sulu Sea. In addition, their chemical 
characteristics (e.g. enrichment of LILE and LREE, depleted HFSE, and typical subduction-related signature) relatively complement each other. The distribution of Sulu Arc which can be traced in eastern Sabah (Chiang 2002) might originated from Sulu Arc regions since Semporna Peninsula located at the end of NE-SE Sulu Arc. Recent zircon U-Pb dating of Semporna volcanic rocks showed the age of Semporna dacite $(12.46 \pm 0.28 \mathrm{Ma})$ is much older than Semporna andesite $(10.49 \pm 0.11 \mathrm{Ma})$ (James \& Azman 2019). Although the U-Pb age reflects that dacite is older than the andesitic unit, the overall REE patterns for Semporna lavas still indicates similar magmatic sources.

Tectonically, Semporna volcanics are plotted into island arc lavas tectonic discrimination diagram of Ti vs. $\mathrm{Zr}$ diagram (Figure 6(a)). Other tectonic discrimination diagrams $\mathrm{Nb} / \mathrm{Yb}$ versus $\mathrm{Th} / \mathrm{Yb}$ (Figure 6(b)) show majority Semporna volcanic rocks plotted within oceanic arcs with one basaltic andesite (13L9) full under active continental margin and alkaline oceanic arcs. Only three rocks samples $($ dacite $=9 \mathrm{~L} 1$ and 9L3; basaltic andesite $=$ 13L9) plotted under island arc Shoshonites while the rest of the Semporna volcanic rocks plotted under island arc calc-alkaline basalt. More specific discrimination diagrams using $\mathrm{Hf} / 3-\mathrm{Th}-\mathrm{Nb} / 16$ and $\mathrm{Hf} / 3-\mathrm{Th}-\mathrm{Ta}$ (Figure 6(c) and 6(d)) shows Semporna volcanic rocks fall into island arc calc-alkaline basalt. The Semporna volcanic rocks might have formed in a back-arc basin, or marginal basin since the Sulu Sea also formed in these settings and currently subducted underneath the Sulu Arc (Pubellier et al. 1991; Rangin \& Silver 1991). After the subduction of Celebes sea beneath the Sulu Arc (Chiang 2002), the Sulu Sea backarc basin was formed followed by subduction rollback towards the south-east (Hall 2013). The volcanic activity was generated by the subduction along Sulu Ridge from Zamboanga Peninsula to southern Sabah during Early to Late Miocene (Rangin \& Silver 1991). The Sulu Arc slowly emerged from sea level and then collapsed during MidMiocene. Most of the Sulu Sea is an extension of former volcanic arc and not an oceanic crust (Hutchison 1992). The subduction of the Celebes Sea was first suggested by Rangin (1989) and then supported by geochemical data (Chiang 2002) and structural data (Hall \& Wilson 2000). Nevertheless, Pre-Neogene volcanic rocks are uncommon in west and central Sabah and more common in eastern part of Sabah.
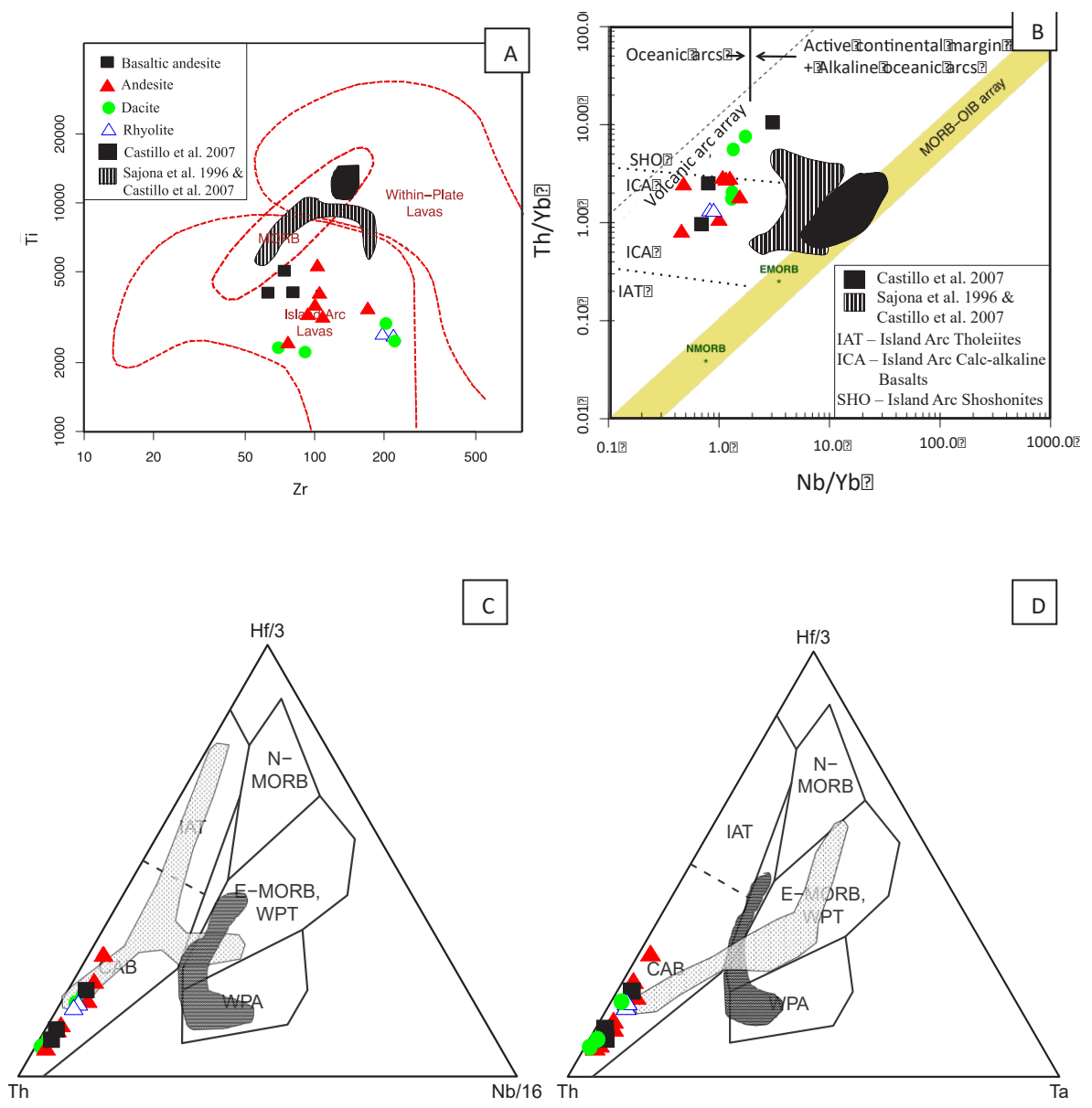

FIGURE 6. Plot of (a) Ti (ppm) vs. Zr (ppm) (after Pearce (1982)), (b) Nb/Yb (ppm) vs. Th/Yb (ppm) diagram (after Pearce (2008)), (c) Hf/3-Th- Nb/16 diagram (after Wood (1980)), and (d) Hf/3-Th-Ta diagram (after Wood (1980)) 


\section{CONCLUSION}

Semporna volcanic rocks are composed of basaltic andesite, andesite, dacite, and rhyolite based on geochemical classification. Semporna volcanic lavas are formed within island arc tectonic environment shows calc-alkaline with minor tholeiitic feature. Geochemical features showed fractionation trends and co-magmatic relationship exist between the basaltic andesite and rhyolite. Large lithophile elements and light rare earth elements enrichment indicated a subduction zone characteristic suggesting Semporna lavas occurred in convergent plate margins with their tectonic setting indicating island arc lavas. The volcanic arc south-east onshore is the continuation of Sulu arc from Zamboanga Peninsula to Semporna based on the geochemical similarity with northeastern Sulu Arc.

\section{ACKNOWLEDGEMENTS}

The authors would like to acknowledge University of Malaya and University Malaysia Kelantan for continuous support. We also like to thank Long Xiang Quek for proofreading this paper and Ms. Angela for the constructive idea of the ArcGIS map. Special appreciation to anonymous referees for their advice, which significantly improved this paper.

\section{REFERENCES}

Balaguru, A., Nicholsk, G. \& Hall, R. 2003. Tertiary stratigraphy and basin evolution of southern Sabah: Implications for the tectonostratigraphic evolution of Sabah, Malaysia. Bulletin of the Geological Society of Malaysia 47: 27-49.

Balaguru, A. \& Hall, R. 2009. Tectonic evolution and sedimentation of Sabah, North Borneo, Malaysia. International Conference and Exhibition of American Association of Petroleum Geologists.

Bellon, H. \& Rangin, C. 1991. Geochemistry and isotopic dating of the Cenozoic volcanic arc sequences around the Celebes and Sulu seas. Proceeding of the Ocean Drilling Program Scientific Results 124: 321-338.

Bergman, S.C., Hutchison, C.S., Swauger, D.A. \& Graves, J.E. 2000. K:Ar ages and geochemistry of the Sabah Cenozoic volcanic rocks. Bulletin of the Geological Society of Malaysia 44: 165-171.

Castillo, P.R., Rigby, S.J. \& Solidum, R.U. 2007. Origin of high field strength element enrichment in volcanic arcs: Geochemical evidence from the Sulu Arc, southern Philippines. Lithos 97(3-4): 271-288.

Chiang, K.K. 2002. Geochemistry of the Cenozoic igneous rocks of Borneo and tectonic implications. PhD Thesis, University of London (Unpublished).

Dhonau, T.J. \& Hutchison, C.S. 1966. The Darvel Bay Area, East Sabah, Malaysia. Malaysia: Malaysia Geological Survey Borneo Region.

Di Vincenzo, G., Andriessen, P.A.M. \& Ghezzo, C. 1996. Evidence of two different components in a Hercynian peraluminous crdierite-bearing granite: The San Basilio Intrusion (Central Sardinia, Italy). Journal of Petrology 37(5): 1175-1206.

Garwin, S., Hall, R. \& Watanabe, Y. 2005. Tectonic setting, geology, and gold and copper mineralization in Cenozoic magmatic arcs of Southeast Asia and the West Pacific. Economic Geology 100th Anniversary Volume 891: 930.

Hall, R. 2013. Contraction and extention in northern Borneo driven by subduction rollback. Journal of Asian Earth Sciences 76: 399-411.

Hall, R. 2012. Late Jurassic-Cenozoic reconstructions of the Indonesian region and the Indian Ocean. Tectonophysics 570-571: 1-41.

Hall, R. \& Wilson, M.E.J. 2000. Neogene sutures in eastern Indonesia. Journal of Asian Earth Sciences 18(6): 787-814.

Haile, N.S., Wong, N.P.Y. \& Nuttall, C.P. 1965. The Geology and Mineral Resources of the Dent Peninsula, Sabah. Sabah: Geological Survey Malaysia.

Hutchison, C.S. 2007. Geological Evolution of South-East Asia. 2nd ed. Kuala Lumpur: Geological Society of Malaysia.

Hutchison, C.S. 1992. The Southeast Sulu Sea, a Neogene marginal basin with outcropping extensions in Sabah. Bulletin of the Geological Society of Malaysia 32: 89-108.

Hutchison, C.S., Bergman, S.C., Swauger, D.A. \& Graves, J.E. 2000. A Miocene collisional belt in north Borneo: Uplift mechanism and isostatic adjustment quantified by thermochronology. Journal of the Geological Society 157(4): 783-793.

Kato, Y., Kano, T. \& Kunugiza, K. 2002. Negative Ce anomaly in the Indian banded iron formations: Evidence for the emergence of oxygenated deep-sea at 2.9 2.7 Ga. Resource Geology 52(2): 101-110.

Kirk, H.J.C. 1968. The Igneous Rocks of Sarawak and Sabah. Malaysia: Geological Survey Borneo Region.

Kirk, H.J.C. 1962. The Geology and Mineral Resources of Semporna Peninsula, North Borneo. Kuching: British Borneo Geology Survey Memoir. p. 14.

Imeokparia, E.G. 1981. $\mathrm{Ba} / \mathrm{Rb}$ and $\mathrm{Rb} / \mathrm{Sr}$ ratios as indicators of magmatic fractionation, postmagmatic alteration and mineralization - afu younger granite complex, Northern Nigeria. Geochemical Journal 15(4): 209-219.

James, E. \& Ghani, A.A. 2019. Zircon U-Pb and Hf isotope constraints on the Neogene Semporna Peninsula volcanic rocks and its tectonic implications. Warta Geologi 45(3): 256-257.

James, E., Ghani, A.A., Asis, J. \& Simon, N. 2019. Subduction roles for nogene volcanic rocks in Semporna Peninsula: Petrology and geochemistry perspective. Sains Malaysiana 48(11): 2473-2481.

Johannesson, K.H., Hawkins, Jr., D.I. \& Cortés, A. 2006. Do Archean chemical sediments record ancient seawater rare earth element patterns? Geochimica et Cosmochimica Acta 70(4): 871-890.

Le Maitre, R.W., Streckeisen, A., Zanettin, B., Le Bas, M.J., Bonin, B., Bateman, P., Dudek, A., Efremova, S., Keller, J., Lameyre, J., Sabine, P.A., Schmid, R., Sorensen, H. \& Wolley, A.R. 1989. Igneous Rocks: A Classification and Glossary of Terms, Recommendations of the International Union of 
Geological Sciences Subcommission on the Systematics of Igneous Rocks. Cambridge: Cambridge University Press.

Lee, D.T.C. 1988. Gunung Pock Area, Semporna Peninsula, Sabah, Malaysia: Explanation of Sheet 4/118/10. Sabah: Geological Survey Malaysia.

Liu, H. 2005. Petrology, geochemistry and geochronology of late Triassic volcanics, Kunlun orogenic belt, western China: Implications for tectonic setting and petrogenesis. Geochemical Journal 39: 1-20.

Macpherson, C.G., Chiang, K.K., Hall, R., Nowell, G.M., Castillo, P.R. \& Thirlwall, M.F. 2010. Plio-Pleistocene intraplate magmatism from the southern Sulu Arc, Semporna peninsula, Sabah, Borneo: Implications for high-Nb basalt in subduction zones. Journal of Volcanology and Geothermal Research 190: 25-38.

Pearce, J.A. 1982. Trace element characteristics of lavas from destructive plate boundaries. In Andesites: Orogenic Andesites and Related Rocks, edited by Thorpe, R.S. England: John Wiley \& Sons. pp. 525-548.

Pearce, J.A. 2008. Geochemical fingerprinting of oceanic basalts with applications to ophiolite classification and the search for Archean oceanic crust. Lithos 100(1-4): 14-48.

Pubellier, M., Quebral, R., Rangin, C., Deffontaines, B., Muller, C., Butterlin, J. \& Manzano, J. 1991. The Mindanao Collision Zone: A soft collision event within a continuous Neogene strike-slip setting. Journal of Southest Asian Earth Sciences 6(3-4): 239-248.

Rangin, C. 1989. The Sulu Sea, a back-arc basin setting within a Neogene collision zone. Tectonophysics 161(1-2): 119-141.

Rangin, C. \& Silver, E.A. 1991. Geological setting of the Celebes and Sulu Sea. Proceedings of the Ocean Drilling Program Scientific Results 124: 35-42.

Rangin, C., Bellon, H., Benard, F., Letouzey, J., Müller, C. \& Tahir, S. 1990. Neogene arccontinent collision in Sabah, N. Borneo (Malaysia). Tectonophysics 183(1-4): 305-319.

Reinhard, M. \& Wenk, E. 1951. Geology of the Colony of North Borneo. Malaysia: Geological Survey Borneo Region.

Sajona, F.G., Maury, R.C., Bellon, H., Cotton, J. \& Defant, M.J. 1996. High field strength element enrichment of PliocenePleistocene island arc basalts, Zamboanga Peninsula, western Mindanao (Philippines). Journal of Petrology 37(3): 693-726.

Sanudin, T., Baba, M. \& Abd. Rahim, I. 2010. Geological heritage features of Tawau volcanic sequence, Sabah. Bulletin of the Geological Society of Malaysia 56: 79-85.

Sanudin, T., Shariff, A.K.O. \& Majeed, M.F. 1995. Middle Miocene volcanic sequence in eastern Sabah. Borneo Science 1(1): 9-27.

Sarbas, B. 2008. The GEOROC database as part of a growing geoinformatics network. In Geoinformatics 2008 - Data to Knowledge. United States: United States Geological Survey.

Sonntag, I., Kerrich, R. \& Hagemann, S.G. 2011. The geochemistry of host arc volcanic rocks to the Co-O epithermal gold deposit, Eastern Mindanao, Philippines. Lithos 127(3-4): 564-580.

Stern, R.J. 2002. Subduction zones. Reviews of Geophysics 40(4): 1012.

Stolz, A.J., Jochum, K.P., Spettel, B. \& Hofmann, A.W. 1996. Fluid- and melt-related enrichment in the subarc mantle:
Evidence from $\mathrm{Nb} / \mathrm{Ta}$ variations in island-arc basalt. Geology 24(7): 587-590.

Swauger, D.A., Bergman, S.C., Marillo, A.P., Pagado, E.S. \& Surat, T. 1995. Tertiary stratigraphy and tectonic framework of Sabah, Malaysia: A field and laboratory study. GEOSEA $958^{\text {th }}$ Regional Conference on Geology, Minerals, and Energy Resources of SE Asia, Manila. pp. 35-36.

Takashima, I., Nazri, A.A., Siong, L.P., Takahiro, K., Mouri, Y., Asnawir, N. \& Eddy, S. 2005. Precise thermoluminescence dating for heat source volcanic rocks and alteration products at the Tawau geothermal Area, Sabah, Malaysia. Proceedings World Geothermal Congress. pp. 24-25.

Tastumi, Y. \& Eggins, S. 1995. Subduction Zone Magmatism. Cambridge: Blackwell Science.

Tjia, H.D., Komoo, I., Aziz, C.A. \& Tahir, S. 1992. Geology of Taman Bukit Tawau, Semporna Peninsula, Sabah. Bulletin of the Geological Society of Malaysia 31: 113-131.

Tongkul, F. 1999. Ancient oceanic crust at Baliajong, Tandek, Kota Marudu, Sabah. In Conservation Geology for Geotope Development, edited by Komoo, I. \& Leman, M.S. Bangi: UKM LESTARI Publication. pp. 299-328.

Tostevin, R., Shields, G.A., Tarbuck, G.M., He, T., Clarkson, M.O. \& Wood, R.A. 2016. Effective use of cerium anomalies as a redox proxy in carbonate-dominated marine settings. Chemical Geology 438: 146-162.

Winchester, J.A. \& Floyd, P.A. 1977. Geochemical discrimination of different magma series and their differentiation products using immobile elements. Chemical Geology 20: 325-343.

Wood, D.A. 1980. The application of a Th-Hf-Ta diagram to problems of tectonomagmatic classification and to establishing the nature of crustal contamination of basaltic lavas of the crustal contamination of basaltic lavas of the British Tertiary Volcanic Province. Earth and Planetary Science Letters 50(1): 11-30.

Xia, L. \& Li, X. 2019. Baslalt geochemistry as a diagnostic indicator of tectonic setting. Gondwana Research 65: 43-67.

Zheng, Y.F. 2019. Subduction zone geochemistry. Geoscience Frontiers 10(4): 1223-1254.

Zhou, P. \& Mukasa, S.B. 1997. Nd-Sr-Pb isotopic, and majorand trace-element geochemistry of Cenozoic lavas from the Khorat Plateau, Thailand: Sources and petrogenesis. Chemical Geology 137(3-4): 175-193.

Elvaene James*

Department of Geoscience

Faculty of Earth Science

Universiti Malaysia Kelantan

17600 Jeli, Kelantan Darul Naim

Malaysia

Elvaene James* \& Azman A. Ghani

Department of Geology

Faculty of Science

Universiti Malaya

50603 Kuala Lumpur, Federal Territory

Malaysia 
Oluwatoyin O. Akinola

Department of Geology

Faculty of Science

Ekiti State University

Ado-Ekiti

Nigeria

Junaidi Asis

Faculty of Science and Natural Resources

University Malaysia Sabah

88400 Kota Kinabalu, Sabah

Malaysia
*Corresponding author; email: Elvaene anne@yahoo.com

Received: 29 February 2020

Accepted: 3 July 2020 